\title{
Combining ability and heterosis in common bean cultivars
}

\author{
Maria Celeste Gonçalves-Vidigal(1), Lucas Silvério(2), Haroldo Tavares Elias ${ }^{(1)}$, Pedro Soares Vidigal Filho(1), \\ Marcus Vinícius Kvitschal( ${ }^{(1)}$, Vanessa Silva Retuci(2) and Claudete Rosa da Silva(1)
}

(1)Universidade Estadual de Maringá, Departamento de Agronomia, Avenida Colombo, o 5790, CEP 87020-900 Maringá, PR, Brazil.
E-mail: mcgvidigal@uem.br, htelias@epagri.sc.gov.br, psvfilho@uem.br, marcusvk78@hotmail.com, clararoze@yahoo.com.br (2)Faculdade Integrado
de Campo Mourão, BR 158, Km 207, CEP 87300-700 Campo Mourão, PR, Brazil. E-mail: silverio@grupointegrado.br, vsretuci@gmail.com

Abstract - The objective of this work was to determine the combining ability and heterosis, for productivity and yield components, in diallel hybrids derived from crossings between BRSMG-Talismã, IPR Uirapuru, FT Soberano, BRS Campeiro, IAC Tybatã, and IPR Juriti parent cultivars. Fifteen hybrids were generated from diallel crosses, excluding reciprocals. The general and specific combining abilities were significant for plant height, number of pods per plant, number of seeds per plant, number of seeds per pod, 50-seed weight, and grain yield, indicating the occurrence of both additive and nonadditive genetic effects. The best strategy to be adopted is the use of BRS Campeiro, FT Soberano and BRSMG-Talismã cultivars in common bean breeding programs involving selection. The most promising combinations were 'IPR Uirapuru' x 'IAC Tybatã', 'IPR Uirapuru' x 'FT Soberano', 'BRS Campeiro' x 'IPR Juriti', and 'BRS Campeiro' x 'IAC Tybatã'. The parents of these hybrids presented high estimates of specific combining abilities. Hybridization of cultivars belonging to distinguished commercial groups propitiates higher heterosis values in the segregant population.

Index terms: Phaseolus vulgaris, additive effects, diallel analysis, interpopulational breeding, intrapopulational breeding, nonadditive effects.

\section{Capacidade combinatória e heterose em cultivares de feijoeiro-comum}

Resumo - O objetivo deste trabalho foi determinar a capacidade combinatória e a heterose, quanto à produtividade de grãos e aos componentes de rendimento, em híbridos derivados dos cruzamentos dialélicos entre as cultivares BRSMG-Talismã, IPR Uirapuru, FT Soberano, BRS Campeiro, IAC Tybatã, e IPR Juriti. Quinze híbridos foram gerados a partir dos cruzamentos dialélicos, sem os recíprocos. As capacidades de combinação geral e específica foram significativas em relação à altura de planta, ao número de vagens por planta, número de sementes por planta, número de sementes por vagem, peso médio de 50 sementes e à produção de grãos, e indicaram a ocorrência de efeitos aditivos e não aditivos. A melhor estratégia a ser adotada em programas de melhoramento que envolvam seleção é o uso das cultivares BRS Campeiro, FT Soberano e BRSMG-Talismã. As combinações mais promissoras foram 'IPR Uirapuru' x 'IAC Tybatã', 'IPR Uirapuru' x 'FT Soberano', 'BRS Campeiro' x 'IPR Juriti' e 'BRS Campeiro' x 'IAC Tybatã'. Os parentais destes híbridos apresentaram elevadas estimativas de capacidade específica de combinação. A hibridização de cultivares pertencentes a grupos comerciais distintos propicia maiores valores de heterose.

Termos para indexação: Phaseolus vulgaris, efeitos aditivos, análise dialélica, melhoramento interpopulacional, melhoramento intrapopulacional, efeitos não aditivos.

\section{Introduction}

Common bean is one of the agricultural products of major socioeconomical importance in Brazil (Ferreira et al., 2006). Beans and rice constitute a food staple of the Brazilian population's diet, especially among the less favoured economic classes. The common bean also constitutes an important source of protein (Ribeiro et al., 2005, 2007), carbohydrates, and iron (Ferreira et al., 2006).
Brazil is the world's greatest common bean producer, followed by India, China, Myanmar, Mexico, and the United States, and produces more than 2.2 million tons, which represent $17.3 \%$ of the world's production. However, Brazilian average yield $\left(852 \mathrm{~kg} \mathrm{ha}^{-1}\right)$ is much lower than the observed in the United States and China, where average productivities reach 1,923 and $1,560 \mathrm{~kg} \mathrm{ha}^{-1}$, respectively (FAO, 2008).

Adoption of common bean breeding practices represents one of the most important strategies for 
elevating grain yield in Brazil. However, the success of common bean breeding programs is intimately related to the appropriate choice of divergent parents which, when crossed, must provide wide genetic variability to be used for selection among segregating populations (Ramalho et al., 1993).

Diallel analysis provides a systematic approach for the detection of appropriate parents and crosses. It also aids plant breeders in choosing the most efficient method for parental selection by allowing them to estimate several genetic parameters (Ramalho et al., 1993). Greater bean grain yield could be obtained by hybridizing superior cultivars.

The diallel analysis method has been widely used by plant breeders to select appropriate parents and crosses and to determine the combining abilities of parents in the early generation. This method was utilized to improve self- and cross-pollinated species (Griffing, 1956).

The use of diallel analysis procedures for choosing parents in Phaseolus vulgaris breeding programs has recently received higher emphasis from bean breeders (Abreu et al., 1999; Barelli et al., 1998, 2000a, 2000b, 2000c; Machado et al., 2002; Silva et al., 2004a, 2004b).

According to Lima et al. (2003), the most commonly used diallel analysis methods are those proposed by Griffing (1956) and Gardner \& Eberhart (1966). Griffing's methodology is based on the effects estimation of the general combining ability (GCA) of possible parents and the specific combining ability (SCA) of the respective hybrid combinations (Cruz et al., 2004). Combining ability describes the breeding value of parental lines to produce hybrids. Sprague \& Tatum (1942) defined general combining ability as the average performance of a line in hybrid combinations, and the specific combining ability as those cases in which certain combinations do better or worse than expected, based on the average performance of the parents involved.

In contrast, the methodology proposed by Gardner \& Eberhart (1966) is based on measurement of the varietal effect, as well as of the heterosis resulting from hybridization between the respective parents (Cruzetal., 2004). Heterosis is defined as superior performance of individual hybrids compared to the phenotypic means of their parents. Regarding previous studies on heterosis in common bean, researchers reported different heterosis values for yield components and plant height characteristics. The amount of exploitable heterosis for common bean yield components ranged from $15.5 \%$ (Albuquerque \& Vieira, 1974) to $35 \%$ (Barelli et al., 1998). Alternatively, for grain yield, Barelli et al. (1998) obtained heterosis estimates up to $23.13 \%$, in hybrids from diallelic crosses among six cultivars of common bean.

Research results demonstrate, therefore, that the diallel analysis can be effective as an initial step in common bean breeding programs, for the identification of parents that provide more productive cultivars.

The objective of the present research was to quantify the effects of heterosis, general combining ability, and specific combining ability on plant height, yield components, and grain yield, among six different common bean cultivars and their diallel hybrids, in order to determine the most appropriate parents and crosses for these investigated traits.

\section{Materials and Methods}

The common bean cultivars BRSMG-Talismã, IPR Uirapuru, FT Soberano, BRS Campeiro, IAC Tybatã, and IPR Juriti were crossed in a diallel system, excluding reciprocals. Selection of the cultivars was based on high productivity potential, commercial characteristics of the grains, adaptability to Minas Gerais and Paraná states, and resistance to the main diseases which occurr in these regions. All cultivars presented undetermined growth habits, and their origin and genealogy are presented in Table 1.

The crosses were carried out from August of 2002 to April of 2003, in the greenhouse of Nupagri (Núcleo de Pesquisa Aplicada a Agricultura), at Universidade Estadual de Maringá, in Maringá County, Northwest of Paraná state, Brazil. Emasculation and pollination were performed by hand using the methodology proposed by Vieira (1967). This method consists of mechanical emasculation of the female parent, by removing the flower buds with tweezers one day before flowering. Emasculation was followed by cross pollination, for which ripe pollen grains from open flowers of male parents were used to perform the crosses. A total of 50 crosses was conducted for each hybrid combination to guarantee a sufficient quantity of seeds to form $F_{1}$ populations of 30 individuals, considering that manual pollinations efficiency was at least of $50 \%$. The $\mathrm{F}_{1}$ 
seeds, obtained through crossings, were multiplied under greenhouse conditions to obtain $\mathrm{F}_{2}$ seeds, which were subsequently used in the field experiment.

The experiment consisted of 21 treatments (six parents and $15 \mathrm{~F}_{2}$ hybrids) and was conducted during the cropping season of 2004, at the experimental station of Epagri (Empresa de Pesquisa Agropecuária e Extensão Rural de Santa Catarina), in Chapecó County, in the Western region of Santa Catarina state, Brazil. The experimental design consisted of randomized complete blocks with three replications. Each plot consisted of two $3 \mathrm{~m}$ long rows with $0.5 \mathrm{~m}$ apart, with 15 plants $\mathrm{m}^{-1}$ and a usable area of $3 \mathrm{~m}^{2}$.

The following six characteristics were assessed: mean final plant height $(\mathrm{PH})$; total number of pods per plant (NPP); mean number of seeds per pod (NSP); mean number of seeds per plant (SP); mean 50-seed weight (SW), obtained by weighing a sample of 50 seeds from each treatment. Grain yield (GY) was expressed in $\mathrm{kg} \mathrm{ha}^{-1}$.

Analysis of variance was carried out for data representing each one of the characteristics (Cruz et al., 2004). Treatment means sum of square partitioning, for general and specific combining ability, was performed according to Griffing (1956), whereas heterosis was estimated by the Gardner \& Eberhart (1966) methodology, both considering Method 2 (parents and $\mathrm{F}_{2}$ hybrids) and Model 1 (fixed effects). This model was adopted because the diallel parents could not be considered as sample of common bean species. The GENES program (Cruz, 2006) was used for analysis.

\section{Results and Discussion}

The analysis of variance showed significant genetic differences at 1 or $5 \%$ probability levels for all the evaluated characteristics. This indicates the existence of significant genetic variability among the evaluated genotypes. Table 2 shows the mean square partitioning of the genotype effects, for the six evaluated characteristics. The mean squares for general combining ability (GCA) and specific combining ability (SCA) were significant for all the characteristics evaluated. However, the mean square effects for GCA were smaller than those obtained for SCA. These results indicate the predominance of nonadditive genetic effect, which

Table 1. Origin and genealogy of the used common bean cultivars.

\begin{tabular}{|c|c|c|c|}
\hline Cultivar & Origin & \multicolumn{2}{|c|}{ Commercial group Genealogy } \\
\hline IPR Juriti ${ }^{(1)}$ & Iapar & Carioca & $\begin{array}{l}\text { Carioca } 99 \text { selection/Great Northern Nebraska 1 Selection \# } 27 \text { // BAT } 93 \\
\text { // Aroana selection // A-176 / A-259 // II - 133 / XAN - } 87\end{array}$ \\
\hline FT Soberano & FT Sementes & Black & FT Tarumã / Mia 2 // FT Rio Preto / Rio Negro \\
\hline IAC Tybatã & IAC & Carioca & L933 x LM30630 \\
\hline BRSMG-Talismã $\tilde{a}^{(2)}$ & UFLA & Carioca & $\begin{array}{l}\text { BAT 477, IAPAR 14, FT 84-29, Jalo EEP, A252, A77, Ojo of Liebre, } \\
\text { ESAL 645, Pintado and Carioca }\end{array}$ \\
\hline BRS Campeiro & Embrapa-CNPAF & Black & $\begin{array}{l}\text { Pedigree method and mass selection in populations from irradiation of } \\
\text { seeds with gamma rays }\left(M_{1} \text { to } M_{6}\right)\end{array}$ \\
\hline IPR Uirapuru & Iapar & Black & Iapar BAC 29 // PR1711//Nep 2// Puebla 173 // ICA Pijao \\
\hline
\end{tabular}

${ }^{(1)}$ Moda-Cirino et al. (2003). (2)Souza et al. (2005).

Table 2. Analysis of variance and combining abilities for plant height (PH), number of pods per plant (NPP), number of seeds per pod (NSP), seeds per plant (SP), 50-seed weight (SW) and grain yield (GY).

\begin{tabular}{|c|c|c|c|c|c|c|c|}
\hline \multirow{2}{*}{$\begin{array}{l}\text { Source of } \\
\text { variation }^{(1)}\end{array}$} & \multirow[t]{2}{*}{$\mathrm{DF}$} & \multicolumn{6}{|c|}{ Evaluated traits } \\
\hline & & $\mathrm{PH}$ & NPP & NSP & SP & SW & GY \\
\hline & & \multicolumn{6}{|c|}{ Mean squares } \\
\hline Cultivar & 20 & $0.018^{* *}$ & $14.573 * *$ & $362.888 * *$ & $0.527 * *$ & $19.610 * *$ & $196,855.73^{*}$ \\
\hline GCA & 5 & $0.039 * *$ & $15.817 * *$ & $480.435^{* *}$ & $1.093 * *$ & $21.488^{*}$ & $209,416.69^{*}$ \\
\hline SCA & 15 & $0.011 * *$ & $14.157 * *$ & $323.705^{* *}$ & $0.340 * *$ & $18.984^{*}$ & $192,668.75^{*}$ \\
\hline Error & 40 & 0.004 & 3.620 & 65.562 & 0.093 & 4.855 & $85,369.21$ \\
\hline & & \multicolumn{6}{|c|}{ Mean square effects } \\
\hline GCA & & 0.001 & 0.508 & 17.286 & 0.042 & 0.693 & $5,168.64$ \\
\hline SCA & & 0.002 & 3.512 & 86.048 & 0.082 & 4.710 & $35,766.51$ \\
\hline Error & & 0.004 & 3.620 & 65.562 & 0.093 & 4.855 & $85,369.21$ \\
\hline
\end{tabular}

${ }^{(1)} \mathrm{GCA}$, general combining ability; SCA, specific combining ability. * and **Significant by F test, at 5 and $1 \%$ of probability, respectively. 
can be explained by the fact that these cultivars were previously selected using a genetic breeding process for growth habit, commercial group, and yield potential (Cruz et al., 2004). Similar results were reported by Machado et al. (2002), who verified the predominance of an additive effect on grain yield in $\mathrm{F}_{2}$ segregant populations, derived from diallel hybrids of common bean. Besides, in relation to the effects of GCA on NPP and SW characteristics, Barelli et al. (2000c) verified a large additive genetic effect.

Table 3 shows the parents' GCA effects $\left(\hat{\mathrm{g}}_{\mathrm{i}}\right)$ for all the evaluated characteristics, as well as the standard deviation between each two parents. 'BRSMG-Talismã', 'IAC Tybatã', and 'IPR Juriti' had positive $\hat{g}_{i}$ values for plant height $(\mathrm{PH})$, which indicates that they should be used as parents in breeding programs designed to increase this characteristic. These cultivars belong to the commercial group Carioca and have an indeterminate growth habit, which may have contributed to the positive $\hat{\mathrm{g}}_{\mathrm{i}}$ value obtained for plant height. Cultivars displaying greater pod and plant height are highly desired, since plant height is related to grain yield (Gonçalves, 1979). In addition, cultivars with a high port tend to present low losses in mechanized harvest schemes, if plant lodging does not occur (Barelli et al., 2000b).

Reduced plant height could be obtained by using BRS Campeiro, IPR Uirapuru, and FT Soberano cultivars as parents in common bean breeding programs, because they had negative $\hat{g}_{\mathrm{i}}$ estimates. Vencovsky \& Barriga (1992) mentioned that a high estimate of GCA for a particular parent indicates a higher or lower concentration of favorable alleles in it compared to the others used in the same diallel crossing. Consequently, high estimates of the general combining ability indicate parental superiority in mean development, compared to other crosses (Griffing, 1956).

Estimation of SCA $\left(\hat{\mathrm{S}}_{\mathrm{ij}}\right)$ for PH indicated that the most promising combination was 'BRSMG-Talismã' x 'IAC Tybatã' (Table 4), which produced an increase in the final height of the resulting populations, as those cultivars demonstrated the highest GCA (Table 3). According to Griffing (1956), superior combinations had the highest $\hat{S}_{\mathrm{ij}}$ values and parents with high GCA. Combination 'IPR Uirapuru' $\mathrm{x}$ 'IPR Juriti' had the highest magnitude of heterosis for PH. Crosses 'BRS Campeiro' x 'IAC Tybatã', however, demonstrated the lowest heterosis value for PH (Table 5).

Regarding number of pods per plant (NPP), the highest estimates of GCA were obtained using cultivars IPR Juriti and IPR Uirapuru (Table 3). This demonstrates that common bean breeding programs can increase the NPP, for which the best combinations were BRSMG-Talismã $\mathrm{x}$ IPR Uirapuru and BRS Campeiro x IPR Juruti cultivars. These combinations presented positive indexes for SCA (Table 4). A single cross provided positive heterosis value for NPP: 'IPR Uirapuru' x 'FT Soberano', but with a very low magnitude (Table 5).

The cultivars IPR Uirapuru and IPR Juriti had positive $\hat{g}_{i}$ values for the number of seeds per plant (SP) (Table 3). Thus, they should be used in breeding programs aiming at increasing grain yield, as there is a significant positive correlation between the number of seeds per plant and grain yield (Bonett et al., 2006). The best combinations for SP were 'IPR Uirapuru' x 'FT Soberano' and 'BRS Campeiro' x 'PR Juruti' (Table 4), which presented high positive SCA values. These combinations are recommended for intrapopulational breeding, because at least one

Table 3. The general combining ability effects $\left(\hat{\mathrm{g}}_{\mathrm{i}}\right)$ for plant height $(\mathrm{PH})$, number of pods per plant (NPP), seeds per plant (SP), number of seeds per pod (NSP), 50-seed weight (SW) and grain yield (GY).

\begin{tabular}{|c|c|c|c|c|c|c|}
\hline \multirow[t]{2}{*}{ Cultivar } & \multicolumn{6}{|c|}{ Evaluated traits } \\
\hline & $\mathrm{PH}$ & NPP & $\mathrm{SP}$ & NSP & SW & GY \\
\hline BRSMG-Talismã & 0.048 & -0.608 & -5.471 & -0.184 & 1.228 & 15.779 \\
\hline IPR Uirapuru & -0.027 & 0.937 & 8.018 & 0.256 & -1.391 & -43.132 \\
\hline FT Soberano & -0.007 & -0.900 & -0.397 & 0.253 & 0.022 & 55.800 \\
\hline BRS Campeiro & -0.061 & 0.189 & 0.044 & -0.0543 & 0.873 & 120.172 \\
\hline IAC Tybatã & 0.037 & -0.559 & -2.381 & -0.023 & -0.406 & -154.708 \\
\hline IPR Juriti & 0.009 & 0.942 & 0.186 & -0.247 & -0.326 & 6.172 \\
\hline Standard deviation & 0.018 & 0.549 & 2.337 & 0.088 & 0.636 & 84.345 \\
\hline
\end{tabular}


parent had a positive GCA value (Table 3). These results indicate that these hybrid combinations present a high potential for obtaining superior lineages with regard to SP. Populations derived from 'BRS Campeiro' $\mathrm{x}$ 'IPR Juriti' and 'IPR Uirapuru' x 'FT Soberano' hybrids were the only ones to present positive heterosis values for this trait. Barelli et al. (1998) reported heterosis values of 1.15 to $22.59 \%$ for SP (Table 5).

With regard to the number of seeds per pod (NSP), positive estimates of GCA were only obtained for IPR Uirapuru and FT Soberano cultivars (Table 3). The results indicate that cultivars BRS Campeiro and BRSMG-Talismã can be used in selective breeding programs to obtain increases in grain yield.

The combinations which demonstrated the highest SCA for NSP were: 'IPR Uirapuru' x 'BRS Campeiro', 'FT Soberano' x 'IAC Tybatã', 'BRS Campeiro' $x$ 'IPR Juriti', 'IPR Uirapuru' x 'FT Soberano', and 'IPR Uirapuru' x 'IPR Juriti' (Table 4). Among these cultivars, only IPR Uirapuru and FT Soberano demonstrated positive GCA values (Table 3). Thus, the best combinations were 'IPR Uirapuru' $\mathrm{x}$ 'BRS Campeiro', 'IPR Uirapuru' x 'FT Soberano', and
'FT Soberano' x 'IAC Tybatã'. The highest heterosis values for NSP were obtained by crossing 'FT Soberano' $x$ 'BRS Campeiro'. The crosses 'IPR Uirapuru' $x$ 'FT Soberano', 'IPR Uirapuru'x 'IPR Juriti', 'FT Soberano' $\mathrm{x}$ 'IAC Tybatã', 'FT Soberano' x 'IPR Juriti', and 'BRS Campeiro' x 'IPR Juriti' demonstrated positive heterosis of over $10 \%$ (Table 5). Previous studies reported that heterosis values ranging from -7.26 to $13.24 \%$ for NSP (Barelli et al., 1998). Ayele (1994) reported heterotic effects in the $\mathrm{F}_{1}$ population from a combination of 'Mexican-142' x 'BAT-1198', which was designed to increase the number of pods and seeds per plant.

For the mean 50-seed weight (SW), BRSMG-Talismã and BRS Campeiro cultivars demonstrated the highest GCA values (Table 3). Even though FT Soberano cultivar presented a positive estimate of general combining ability, its magnitude was low. Thus, this cultivar displayed an average behavior, in relation to the other parents used in this cross. This could be explained by the fact that this characteristic exhibited a nonadditive predominant effect (Table 2). However, due to

Table 4. The specific combining ability effects $\left(\hat{\mathrm{S}}_{\mathrm{ij}}\right)$ of hybrids for plant height $(\mathrm{PH})$, number of pods per plant (NPP), seeds per plant (SP), number of seeds per pod (NSP), 50-seed weight (SW) and grain yield (GY).

\begin{tabular}{|c|c|c|c|c|c|c|}
\hline \multirow[t]{2}{*}{ Cross-combination } & \multicolumn{6}{|c|}{ Evaluated characteristics } \\
\hline & $\mathrm{PH}$ & NPP & SP & NSP & SW & GY \\
\hline $1 \times 1$ & -0.030 & 2.043 & 12.740 & 0.400 & -4.250 & -90.830 \\
\hline $1 \times 2$ & -0.030 & -0.360 & -6.240 & -0.340 & 1.420 & 153.850 \\
\hline $1 \times 3$ & -0.010 & -0.470 & -1.530 & 0.030 & 0.940 & 61.490 \\
\hline $1 \times 4$ & -0.020 & -2.24 & -6.14 & 0.212 & 2.180 & 83.130 \\
\hline $1 \times 5$ & 0.140 & -0.350 & -7.090 & -0.510 & 2.500 & 143.200 \\
\hline $1 \times 6$ & -0.060 & -0.670 & -4.480 & -0.200 & 1.440 & 62.880 \\
\hline $2 \times 2$ & -0.022 & 1.870 & 5.590 & -0.180 & -2.490 & -134.090 \\
\hline $2 \times 3$ & 0.030 & 1.750 & 12.540 & 0.310 & 0.070 & 374.260 \\
\hline $2 \times 4$ & -0.040 & -1.090 & -3.620 & 0.900 & -0.050 & 4.080 \\
\hline $2 \times 5$ & -0.030 & -2.250 & -10.580 & -0.010 & 3.830 & 389.150 \\
\hline $2 \times 6$ & 0.120 & -1.780 & -3.270 & 0.300 & -0.300 & -149.950 \\
\hline $3 \times 3$ & -0.051 & 1.770 & 0.570 & -0.530 & -1.010 & -86.480 \\
\hline $3 \times 4$ & 0.050 & -1.420 & -4.560 & 0.130 & 1.070 & 20.980 \\
\hline $3 \times 5$ & 0.010 & -1.070 & -0.170 & 0.440 & -0.680 & -94.870 \\
\hline $3 \times 6$ & 0.030 & -2.340 & -7.450 & 0.160 & 0.610 & 146.100 \\
\hline $4 \times 4$ & 0.026 & 0.370 & -2.930 & -0.310 & -1.340 & -94.580 \\
\hline $4 \times 5$ & -0.060 & -0.690 & -4.690 & -0.140 & 1.940 & 198.060 \\
\hline $4 \times 6$ & 0.020 & 4.700 & 24.860 & 0.330 & -2.470 & 219.600 \\
\hline $5 \times 5$ & -0.010 & 2.820 & 14.550 & 0.180 & -4.660 & -127.740 \\
\hline $5 \times 6$ & -0.020 & -1.290 & -6.570 & -0.140 & 1.750 & 74.100 \\
\hline $6 \times 6$ & -0.050 & 0.680 & -1.540 & -0.220 & -0.520 & -63.580 \\
\hline$\overline{\mathrm{SD}}_{(\mathrm{Sii}-\mathrm{Sij})}{ }^{(1)}$ & 0.036 & 1.099 & 4.675 & 0.176 & 1.272 & 168.690 \\
\hline $\mathrm{SD}_{(\mathrm{Sij}-\mathrm{Sik})}$ & 0.048 & 1.453 & 6.184 & 0.233 & 1.683 & 223.156 \\
\hline $\mathrm{SD}_{(\mathrm{Sij}-\mathrm{Skl})}$ & 0.045 & 1.345 & 5.725 & 0.216 & 1.558 & 206.602 \\
\hline
\end{tabular}

${ }^{(1)}$ Standard deviation. 
superior agronomical conditions and high productive potential of FT Soberano cultivar, it could still be used in common bean breeding programs involving hybridization, in order to obtain cultivars with greater seed weight.

Eleven combinations exhibited positive SCA values for SW (Table 4). Among these, the following combinations had at least one parent with a positive GCA value: 'BRSMG-Talismã' $\mathrm{x}$ 'IAC Tybatã', 'BRSMG-Talismã' x 'BRS Campeiro', 'BRS Campeiro' x 'IAC Tybatã', 'BRSMG-Talismã' x 'IPR Juriti', and 'BRSMG-Talismã' x 'IPR Uirapuru'. All these crosses tend to provide lineage selection producing grains of a high specific mass. The combination 'IPR Uirapuru' $\mathrm{x}$ 'IAC Tybatã' presented the highest SCA, even though neither of these parents presented positive values of GCA. The high degree of genetic complementation between these parents explains their high values for SCA (Machado et al., 2002). Seed weight presented the highest heterosis values among all other studied traits: 'IPR Uirapuru' x 'IAC Tybatã' and 'BRSMG-Talismã' x 'IAC Tybatã', had extremely high heterosis values of 138.94 and $98.35 \%$, respectively (Table 5). The lowest heterosis values for this trait were observed in 'BRS Campeiro' x 'IPR Juriti'.
For grain yield (GY), 'BRS Campeiro', 'FT Soberano', and 'BRSMG-Talismã' cultivars demonstrated the highest general combining ability values (Table 3 ). The cultivar IAC Tybatã had the largest negative value for GCA, demonstrating the inferiority of this cultivar in relation to the others, regarding GY.

All hybrid combinations except for 'IPR Uirapuru' x 'IPR Juriti' and 'FT Soberano' x 'IAC Tybatã' presented positive and high $\hat{\mathrm{S}}_{\mathrm{ij}}$ values for GY (Table 4). The hybrid combinations exhibiting the highest values for $\hat{S}_{\mathrm{ij}}$ were: 'IPR Uirapuru' x 'IAC Tybatã', 'IPR Uirapuru' $x$ 'FT Soberano', 'BRS Campeiro' x 'IPR Juriti', and 'BRS Campeiro' x 'IAC Tybatã'. As observed for SW (Table 4), 'IPR Uirapuru' x 'IAC Tybatã' combination was not expected to stand out, because both parents had negative $\hat{g}_{i}$ values (Table 3); hybrids tend to exhibit better phenotypic performance when the parental strains present a high GCA (Griffing, 1956). In contrast, even when both parents present negative $\hat{g}_{\mathrm{i}}$ values, this high $\hat{\mathrm{S}}_{\mathrm{ij}}$ value can be explained by high complementation between the parents, resulting in increased grain yield (Machado et al., 2002). Thus, hybrid combinations of 'IPR Uirapuru' x 'IAC Tybatã', 'IPR Uirapuru' x 'FT Soberano', 'BRS Campeiro' x 'IPR Juriti', and 'BRS Campeiro' x 'IAC Tybatã' tend to

Table 5. Plant height (PH), number of pods per plant (NPP), seeds per plant (SP), number of seeds per pod (NSP), 50-seed weight (SW), grain yield (GY) and heterosis values, in relation to the parental mean $(\mathrm{H})$.

\begin{tabular}{|c|c|c|c|c|c|c|c|c|c|c|c|c|}
\hline \multirow[t]{2}{*}{$\overline{\text { Genotype }}^{(1)}$} & \multicolumn{2}{|c|}{$\mathrm{PH}(\mathrm{cm})$} & \multicolumn{2}{|c|}{ NPP } & \multicolumn{2}{|c|}{ SP } & \multicolumn{2}{|c|}{ NSP } & \multicolumn{2}{|c|}{ SW $(\mathrm{g})$} & \multicolumn{2}{|c|}{ GY(g per plant) } \\
\hline & Mean & $\mathrm{H}(\%)$ & Mean & $\mathrm{H}(\%)$ & Mean & $\mathrm{H}(\%)$ & Mean & $\mathrm{H}(\%)$ & Mean & $\mathrm{H}(\%)$ & Mean & $\mathrm{H}(\%)$ \\
\hline 1 & 0.83 & - & 14.59 & - & 59.50 & - & 4.24 & - & 8.92 & - & $1,375.0$ & - \\
\hline 2 & 0.67 & - & 17.50 & - & 79.33 & - & 4.54 & - & 5.44 & - & $1,137.0$ & - \\
\hline 3 & 0.68 & - & 13.73 & - & 57.5 & - & 4.18 & - & 9.75 & - & $1,466.7$ & - \\
\hline 4 & 0.65 & - & 14.51 & - & 54.87 & - & 3.79 & - & 11.12 & - & $1,573.2$ & - \\
\hline 5 & 0.81 & - & 15.47 & - & 67.5 & - & 4.34 & - & 5.23 & - & 931.5 & - \\
\hline 6 & 0.71 & - & 16.33 & - & 56.53 & - & 3.49 & - & 9.54 & - & $1,431.5$ & - \\
\hline $1 \times 2$ & 0.74 & -1.77 & 13.73 & -14.39 & 54.01 & -22.18 & 3.94 & -10.14 & 11.99 & 67.03 & $1,722.2$ & 37.18 \\
\hline $1 \times 3$ & 0.78 & 3.30 & 11.78 & -16.78 & 50.31 & -14.00 & 4.31 & 2.33 & 12.91 & 38.32 & $1,728.7$ & 24.67 \\
\hline $1 \times 4$ & 0.71 & -3.58 & 11.10 & -23.72 & 46.14 & -19.30 & 4.19 & 4.27 & 15.00 & 49.70 & $1,814.9$ & 23.12 \\
\hline $1 \times 5$ & 0.97 & 17.81 & 12.24 & -18.54 & 42.77 & -32.65 & 3.49 & -18.57 & 14.03 & 98.35 & $1,600.0$ & 38.72 \\
\hline $1 \times 6$ & 0.75 & -3.22 & 13.43 & -13.15 & 47.94 & -17.36 & 3.57 & -7.58 & 13.06 & 41.43 & $1,680.6$ & 19.76 \\
\hline $2 \times 3$ & 0.74 & 9.09 & 15.54 & 0.47 & 77.87 & 13.81 & 5.02 & 15.34 & 9.41 & 23.98 & $1,955.6$ & 50.22 \\
\hline $2 \times 4$ & 0.62 & -7.03 & 13.79 & -13.82 & 62.15 & -7.37 & 4.50 & 8.08 & 10.14 & 22.40 & $1,676.9$ & 23.74 \\
\hline $2 \times 5$ & 0.72 & -2.23 & 11.88 & -27.87 & 52.76 & -28.13 & 4.44 & 0.04 & 12.75 & 138.94 & $1,787.0$ & 72.78 \\
\hline $2 \times 6$ & 0.85 & 23.26 & 13.86 & -18.09 & 62.64 & -7.79 & 4.52 & 12.58 & 8.69 & 16.06 & $1,409.3$ & 9.73 \\
\hline $3 \times 4$ & 0.73 & 9.23 & 11.63 & -17.67 & 52.80 & -6.12 & 4.53 & 123.76 & 12.68 & 21.53 & $1,792.6$ & 17.94 \\
\hline $3 \times 5$ & 0.78 & 4.23 & 11.23 & -23.06 & 54.76 & -12.38 & 4.88 & 14.55 & 9.64 & 28.72 & $1,401.9$ & 16.91 \\
\hline $3 \times 6$ & 0.78 & 11.90 & 11.46 & -23.79 & 50.04 & -12.23 & 4.37 & 13.90 & 11.02 & 14.22 & $1,803.7$ & 24.47 \\
\hline $4 \times 5$ & 0.66 & -9.54 & 12.70 & -15.26 & 82.80 & -17.17 & 3.99 & -1.93 & 13.12 & 60.42 & $1,759.3$ & 40.48 \\
\hline $4 \times 6$ & 0.72 & 5.11 & 19.59 & 27.07 & 48.94 & 48.65 & 4.24 & 16.34 & 8.79 & -14.92 & $1,941.7$ & 29.24 \\
\hline $5 \times 6$ & 0.77 & 0.65 & 12.85 & -19.18 & 53.09 & -21.08 & 3.79 & -3.15 & 11.73 & 58.77 & $1,431.5$ & 28.76 \\
\hline
\end{tabular}

(1)1: 'BRSMG-Talismã'; 2: 'IPR Uirapuru'; 3: 'FT Soberano'; 4: 'BRS Campeiro'; 5: 'IAC Tybatã'; 6: 'IPR Juriti'. 
generate promising segregant populations for selection of lineages with high productive potential. The heterosis values estimated for GY (Table 5) ranged from 9.73\% ('IPR Uirapuru' x 'IPR Juriti') to $72.78 \%$ ('IPR Uirapuru' x 'IAC Tybatã'). Similar results were reported by Barelli et al. (1998), who reported heterosis values from 4.53 to $23.13 \%$. Such results demonstrate that prior analysis of heterosis, when selecting parents in common bean breeding programs, provides reliable information to help bean breeders. It is noteworthy that the highest heterosis value was shown by the segregant population derived from 'IPR Uirapuru' x 'IAC Tybatã' cross, which represents strains belonging to the different Black and Carioca commercial groups, respectively.

In the black commercial group, the most promising hybrid combinations were 'IPR Uirapuru' x 'FT Soberano', 'BRS Campeiro' x 'FT Soberano', and 'IPR Uirapuru' $x$ 'BRS Campeiro', as they have presented the highest $\hat{S}_{\mathrm{ij}}$ values (Table 4). It is important to remember that this commercial group is the most accepted in the Southern region of Paraná and Santa Catarina states (Elias et al., 2007). Hence, these cultivars could be widely utilized, mainly in common bean breeding programs designed to develop adaptive varieties for these regions.

Nevertheless, the Brazilian bean market preference is, in general, the commercial Carioca group (FIEP, 2006). Thus, crosses between 'BRSMG-Talismã' $\mathrm{x}$ 'IAC Tybatã', 'BRSMG-Talismã' $x$ 'IPR Juriti', and 'IAC Tybatã'x 'IPR Juriti' appear to be the most favorable in generating promising segregant populations for the extraction of highly productive lineages.

\section{Conclusions}

1. Both additive and nonadditive gene effects control grain yield and yield components in common bean.

2. The cultivars BRSMG Talismã and IPR Juriti, from Carioca commercial group, and cultivars BRS Campeiro and FT Soberano, from the Black commercial group, have potential for obtaining superior lineages in selection programs for grain yield.

3. 'IPR Uirapuru' x 'FT Soberano', from the Black commercial group, and 'BRS Campeiro' x 'FT Soberano', from the Carioca commercial group, are the most promising crosses for obtaining more productive lineages.

4. Hybridization of cultivarsbelongingtodistinguished commercial groups propitiates higher heterosis values in the segregant population.

\section{Acknowledgements}

To Coordenação de Aperfeiçoamento de Pessoal de Nível Superior and to Conselho Nacional de Desenvolvimento Científico e Tecnológico, for financial support and scholarship; to Pedrina Gonçalves Vidigal for reviewing the manuscript.

\section{References}

ABREU, A. de F.B.; RAMALHO, M.A.P.; FERREIRA, D.F. Selection potential for seed yield from intra- and inter-racial populations in common bean. Euphytica, v.108, p.121-127, 1999.

ALBUQUERQUE，M.M. de; VIEIRA，C. Manifestações da heterose em Phaseolus vulgaris L. Revista Ceres, v.21, p.148-166, 1974.

AYELE, M. Diallel analyses for yield and yield components in haricot bean, Phaseolus vulgaris. Annual Report of Bean Improvement Cooperative, v.37, p.159-160, 1994.

BARELLI, M.A.A.; GONÇALVES-VIDIGAL, M.C.; AMARAL JÚNIOR, A.T. do; VIDIGAL FILHO, P.S.; SCAPIM, C.A. Combining ability among common bean cultivars adapted to the Northwest region of Paraná State, Brazil. Bragantia, v.59, p.159-164, 2000a.

BARELLI, M.A.A.; GONÇALVES-VIDIGAL, M.C.; AMARAL JÚNIOR, A.T. do; VIDIGAL FILHO, P.S.; SCAPIM, C.A. Diallel analysis of the combining ability of common bean (Phaseolus vulgaris L.) cultivars. Brazilian Archives of Biology and Technology, v.43, p.409-414, 2000 b.

BARELLI, M.A.A.; GONÇALVES-VIDIGAL, M.C.; AMARAL JÚNIOR, A.T. do; VIDIGAL FILHO, P.S.; SCAPIM, C.A. Heterose relativa em feijoeiro (Phaseolus vulgaris L.). Acta Scientiarum. Agronomy, v.20, p.257-262, 1998.

BARELLI, M.A.A.; GONÇALVES-VIDIGAL, M.C.; AMARAL JÚNIOR, A.T. do; VIDIGAL FILHO, P.S.; SCAPIM, C.A.; SAGRILO, E. Diallel analysis for grain yield components in Phaseolus vulgaris L. Acta Scientiarum. Agronomy, v.22, p.883-887, 2000c.

BONETT, L.P.; GONÇALVES-VIDIGAL, M.C.; SCHUELTER, A.R.; VIDIGAL FILHO, P.S.; GONELA, A.; LACANALLO, G.F. Divergência genética em germoplasma de feijoeiro-comum coletado no Estado do Paraná, Brasil. Semina. Ciências Agrárias, v.27, p.547-560, 2006.

CRUZ, C.D. Programa Genes: biometria. Viçosa: UFV, 2006. $382 \mathrm{p}$.

CRUZ, C.D.; REGAZZI, A.J.; CARNEIRO, P.C.S. Modelos biométricos aplicados ao melhoramento genético. Viçosa: UFV, 2004. v.1. 480p.

ELIAS, H.T.; GONCALVES-VIDIGAL, M.C.; GONELA, A.; VOGT, G.A. Variabilidade genética em germoplasma tradicional de feijão-preto em Santa Catarina. Pesquisa Agropecuária Brasileira, v.42, p.1443-1449, 2007. 
FAO. Food and Agriculture Organization of the United Nations. Production: crops primary: cassava. Available at: $<$ http://faostat. fao.org/>. Accessed on: 15 Aug. 2008.

FERREIRA, C.M.; SANTOS, M.L. dos; BRAGA, M.J.; DEL PELOSO, M.J. Aspectos econômicos. In: VIEIRA, C.; PAULA JÚNIOR, T.J.; BORÉM, A. (Ed.). Feijão. Viçosa: UFV, 2006. p.19-40.

FIEP. Federação das Indústrias do Estado do Paraná. Programa de aumento das vendas dos produtos paranaenses: feijão, versão 1.0, 2006. 15p. Available at: <http://www.fiepr.org. $\mathrm{br} /$ fiepr//conselhos/agroindustria_alimentos/uploadAddress/ Relat\%C3\%B3rioFeij\%C3\%A3o0506.pdf $>$. Accessed on: 22 Aug. 2008.

GARDNER, C.O.; EBERHART, S.A. Analysis and interpretation of variety cross diallel and related populations. Biometrics, v.22, p.439-452, 1966.

GONÇALVES, M.C. Correlações genotípicas, fenotípicas e de ambiente em feijoeiro (Phaseolus vulgaris L.). 1979. 42p. Tese (Mestrado) - Universidade Federal de Viçosa, Viçosa.

GRIFFING, B. Concept of general and specific combining ability in relation to diallel crossing systems. Australian Journal of Biology Science, v.9, p.463-493, 1956.

LIMA, P.C.; FERREIRA, D.F.; BUENO FILHO, J.S. de S.; RAMALHO, M.A.P. Somas de quadrados e hipóteses associadas ao modelo dialélico de Gardner e Eberhart. Ciência e Agrotecnologia, v.27, p.1113-1121, 2003.

MACHADO, C. de F.; SANTOS, J.B. dos; NUNES, G.H. de S.; RAMALHO, M.A.P. Choice of common bean parents based on combining ability estimates. Genetics and Molecular Biology, v.25, p.179-183, 2002.

MODA-CIRINO, V.; OLIARI, L.; FONSECA JÚNIOR, N. da S.; LOLLATO, M.A. IPR Juriti: common bean cultivar. Crop Breeding and Applied Biotechnology, v.3, p.303-306, 2003.
RAMALHO, M.A.P.; SANTOS, J.B. dos; ZIMMERMANN, M.J.O. Genética quantitativa em plantas autógamas: aplicações ao melhoramento do feijoeiro. Goiânia: UFG, 1993. 271p.

RIBEIRO, N.D.; LONDERO, P.M.G.; CARGNELUTTI FILHO, A.; JOST, E.; POERSCH, N.L.; MALLMANN, C.A. Composição de aminoácidos de cultivares de feijão e aplicações para o melhoramento genético. Pesquisa Agropecuária Brasileira, v.42, p.1393-1399, 2007.

RIBEIRO, N.D.; LONDERO, P.M.G.; HOFFMANN JUNIOR, L.; POERSCH, N.L.; CARGNELUTTI FILHO, A. Dissimilaridade genética para teor de proteína e fibra em grãos de feijão dos grupos preto e de cor. Revista Brasileira de Agrociência, v.11, p.167-173, 2005.

SILVA, M.P.; AMARAL JÚNIOR, A.T. do; RODRIGUES, R.; DAHER, R.F.; LEAL, N.R.; SCHUELTER, A.R. Análise dialélica da capacidade combinatória em feijão-de-vagem. Horticultura Brasileira, v.22, p.277-280, 2004a.

SILVA, M.P.; AMARAL JÚNIOR, A.T. do; RODRIGUES, R.; PEREIRA, M.G.; VIANA, A.P. Genetic control on morphoagronomic traits in snap bean. Brazilian Archives of Biology and Tecnology, v.47, p.855-862, $2004 \mathrm{~b}$.

SOUZA, T.L.P.O. de; RAGAGNIN, V.A.; MELO, C.L.P. de; ARRUDA, K.M.A.; CARNEIRO, J.E. de S.; MOREIRA, M.A.; BARROS, E.G. de. Phenotypic and molecular characterization of cultivar BRSMG-Talismã regarding the principal common bean pathogens. Crop Breeding and Applied Biotechnology, v.5, p.247-252, 2005.

SPRAGUE, G.F.; TATUM, L.A. General vs. specific combining ability in single crosses of corn. Journal of American Society of Agronomy, v.34, p.923-932, 1942.

VENCOVSKY, R.; BARRIGA, P. Genética biométrica no fitomelhoramento. Ribeirão Preto: Sociedade Brasileira de Genética, 1992. 486p.

VIEIRA, C. O feijoeiro comum: cultura, doenças e melhoramento. Viçosa: UFV, 1967. 220p.

Received on June 14, 2008 and accepted on August 28, 2008 